Stellenbosch Theological Journal 2021, Vol 7, No 1, 1-18

DOI: http://dx.doi.org/10.17570/stj.2021.v7n1.a21

Online ISSN 2226-2385 | Print ISSN 0028-2006

2021 @ Pieter de Waal Neethling Trust

\title{
Die Volkskerk van Afrika en eerwaarde J.J.H. Forbes se teologie van antidiskriminasie, selfhelp en opvoeding
}

\author{
Donald J Katts \\ Universiteit Stellenbosch \\ Stellenbosch, Suid-Afrika \\ donaldjkatts@gmail.com
}

\begin{abstract}
The Volkskerk van Afrika and Reverend J.J.H. Forbes' theology of anti-discrimination, selfhelp, and education

This article wishes to analyse the key elements in the theology of the founder and first minister of the Volkskerk van Afrika, especially as regards anti-discrimination, self-help, and education. In order to understand the theology of Forbes, it is necessary to portray the historical rise of the Volkskerk van Afrika as a Christian Church with special reference to the circumstances surrounding the establishment of the Church in 1922. Thirdly, it is intended to discuss the relevance of the Volkskerk van Afrika for today.
\end{abstract}

\section{Keywords}

Volkskerk van Afrika; theology; anti-discrimination; self-help; education; J.J.H. Forbes

\section{Inleiding}

14 Mei 1922 is nie net die stigtings- en toewydingsdag van die Volkskerkvan Afrika ${ }^{1}$ nie. Dit is 'n dag en tyd wat heenwys en lidmate herinner aan die rassespanning en gruwelike onderdrukking, ontkenning van mense se beeldskap van God, en die ontneming van geleenthede van veral swarten bruin mense in Suid-Afrika. Hierdie onderdrukking en ontkenning was nie net op politieke, ekonomiese en sosiale vlakke ervaar nie; maar

1 Sien Botha (1973), waar die verskillende betekenisse van "Volkskerk" uiteengesit word. 
onderdrukking en diskriminasie het ook sy kop in die geestelike sfeer, die kerk en Christelike godsdiens van die dag uitgesteek. Dit is teen hierdie agtergrond dat J.J.H. Forbes, as stigter, se teologie van antidiskriminasie, selfhelp en opvoeding so 'n groot impak op die groei van die Volkskerk van Afrika gehad het.

14 Mei 1922 is ook die dag wat dien as bewys van wat veral bruinmense kan doen, bereik en waartoe hulle in staat is naamlik selfbestuur, onafhanklikheid, diensbaarheid vir God, medemens en vaderland. Forbes en sy medestigters wou juis 'n Kerk vir die bruingemeenskap stig om te wys dat hul vermoëns, verantwoordelikheidsin en menswaardigheid nie deur'n groep witmense se opinies bepaal kan word nie. Hulle wou ook 'n Kerk in die lewe roep wat as andere se gelykes kon meewerk om van Suid-Afrika 'n beter plek te maak. Hierdie visie van Forbes, asook van sy helpers, het die mense met hoop geïnspireer en mense het hul tot die droom verbind om 'n eie kerk te hê. Piet Naudé skryf juis in sy boek Onder die skewe reënboog 'n evangelie van hoop vir gewone mense in 'n gekwelde land: en sê: "Ek meen die kerk is nie net nodig vir hoop nie; die kerk is aan die wêreld hoop verskuldig" (1999:66).

Die geesdrif, oortuigings en beginsels van die stigterlede en families, van Kaapstad sowel as van Stellenbosch, het gou opslae gemaak en mense van verskeie denominasies getrek. Ook het mense van alle statuur, intellek, beroepe en talente, die Volkskerk van Afrika (toe nog beweging) ondersteun terwyl ander lidmate geword het. Hiervan getuig onder andere Forbes, wat onderwyser en skoolhoof was, en Paul Rhode, 'n haarkapper.

Uit die wit gemeenskap was daar advokaat M. Alexander en hoofregter James Rose-Innes wat die stigting van die Volkskerk van Afrika goedgesind was. The Western Province Amateur Musical Society is ook as vriend van die Volkskerk van Afrika beskou. Dr F.M. Gow van die African Methodist Episcopal Church wat ook by verskeie geleenthede van die Volkskerk van Afrika opgetree het, is bewyse van die statuur van mense wat die Volkskerk van Afrika gerugsteun het. Dit is interessant dat daar in die bronne geen melding gemaak word van enige amptelike ondersteuning wat die Volkskerk van Afrika van bruin kerke of enige ander kerk geniet het nie.

Sedert 1922 het die Volkskerk van Afrika as Christelike denominasie gegroei tot waar hulle vandag bestaan uit 26 selfstandige gemeentes, 16 
dienende predikante (waarvan 2 hul doktorsgrade verwerf het) en 4 wat of afgetree of sonder gemeente is. Die Volkskerk van Afrika beskou homself as 'n kerk met gereformeerde teologiese wortels en mak deel uit van verskillende ekumeniese liggame, soos byvoorbeeld die Wêreldbond van Gereformeerde Kerke (World Communion of Reformed Churches - gestig in 2010, in Grand Rapids, Michigan, Amerika).

\section{Eerwaarde Forbes: biografiese aantekeninge ${ }^{2}$}

Forbes (een van twaalf kinders ${ }^{3}$ van John en Helena Forbes, van die plaas Heatherdale op die Kaap se vlakte), is in Claremont op 13 Februarie 1876 gebore. Hy het in 'n atmosfeer van nugterheid en vroomheid grootgeword vir'n groot deel van sy jeug op sy vader se plaas, Heatherdale, Wes-Londen, nou bekend as Athlone, deurgebring. In 1906 het hy hom as onderwyser bekwaam en die aanstelling as skoolhoof in die gebied verkry. Drie jaar later het hy met Rebecca Rosina Peters in die huwelik getree. Na haar dood in 1937 trou hy later met J.C. West, die suster van sy eerste vrou.

Hy was eers ' $n$ evangelis by die Wesleyaanse Metodiste Kerk, waarna hy hom as predikant kwalifiseer en op 22 Julie 1918 georden is. Hy het onderskeidelik in Soutrivier en later in Mowbray sy bediening voortgesit. Weens verskille oor die kleurvraagstuk, het hy die kerk verlaat en by die Congregational Kerk aangesluit. Hy het om dieselfde redes ook hierdie kerk verlaat en sou later op 14 Mei 1922 die Volkskerk van Afrika stig.

Hy was'n sterk leier met'n visie om 'n verskil te maak, nie net met betrekking tot die politieke, ekonomiese en sosiale sake nie, maar ook met betrekking tot die opvoeding en geestelike aspekte van veral die bruin mense. Hy wou ook as mens, opvoeder en kerkleier die bruin gemeenskap help verstaan wat dit beteken om 'n Christen te wees.

Hy het by verskeie geleenthede teen die apartheidsbeleid uitgevaar, diskriminasie van enige aard veroordeel en gepleit vir gelyke behandeling

2 Die predikante van die Volkskerk van Afrika is aanvanklik as "eerwaarde" aangespreek. Dit het in later jare na "dominee" verander.

3 John en Helena Forbes, ouers van eerwaarde J.J.H. Forbes het ses seuns en ses dogters gehad (Die Burger 1928). 
van alle mense. In Oktober 1948 met die inwyding van die Strand gemeente, noem hy die volgende,

Die Volkskerk van Afrika staan op gelyke voet met enige ander kerk in die land - en ons sal glad nie aan die voet van 'n ander lê nie.

Daarom sal daar by ons geen toegewing aan apartheid wees nie.

Apartheid is regstreeks teen die leer van Christus. Die Volkskerk van

Afrika staan vierkantig teen apartheid (The Torch 1948:6).

Forbes het reeds in 1927 toe hy genomineer is om op die skoolraad te dien, hom vir vrye en verpligte opvoeding beywer. ${ }^{4} \mathrm{Hy}$ het ondermeer in sy tyd sewe kerkskole en 'n weeshuis in Jonkersdam onder sy bestuur gehad. Hy het hom beywer om die beleid van selfhelp eie aan die Volkskerk van Afrika te maak. Die beleid het daartoe bygedra dat daar vanuit die blanke gemeenskap ondersteuning gekom het.

Met Forbes se wegbreek van die Congregational Kerk het hy geen heenkome gehad nie:

Extreme hardship followed the transition. The pastor and family were scattered - the children went to his parents, Heatherdale Farm. The pastor, and ms Forbes to his sister (ms Katts, Rondebosch), and the furniture stored in a house in Blythe Street, Cape Town. This went on for months (Volkskerk van Afrika, Silver Jubilee 1947:10).

Die Volkskerk van Afrika se gemeente van Kaapstad het na die Forbesfamilie omgesien.

Die volgende beskrywings van sy tydsgenote en kollegas is dalk meer 'n raak opsomming van Forbes se geestelikheid of spiritualiteit. Volgens eerwaarde D. Janari was Forbes 'n man van gebed wat God baie liefgehad het. Ds J.A. Classen beskryf Forbes was 'n man van orde, wat taai kon vashou aan sy oortuigings, iemand wat 'n groot patriot was en vir wie sy geboorteland na aan sy hart was. Hy noem verder dat Forbes sy lewe lank teen onderskeidmakende wetgewing, op grond van kleur, geveg het.

4 In een van Forbes se verkiesingspamflette noem hy dat daar te min skole vir die bruin mense is. Die ratio van publieke skole teenoor die skole vir die bruin mense het destyds soos volg daaruit gesien: Hoërskole, 12 tot 1; sekondêre skole, 5 tot 0 ; primêre skole, 63 tot 7; aandskole, 6 tot 3 . Ook wys hy daarop dat die bouprogramme $£ 21000$ tot $£ 1,150$ baie onregverdig is (School Board Elections 1927:1). 
Forbes was ook 'n man van selfrespek, was 'n vredemaker wat met sy sagte antwoorde en gewoonte om te swyg, só hewige brande geblus het. Ook word Forbes beskryf as 'n man van voorbeeld - in sy huis, kerk en samelewing. Op geestelike gebied was Forbes, soos dit van 'n leraar verwag word, altyd fatsoenlik en kuis, ernstig en nougeset. Lawwe grappies, verspotheid en ongepasthede was dinge wat hy verafsku het (Sien Volkskerk van Afrika, 34ste kerkverjaarsdag 1956:1-11). Hierdie spiritualiteit van Forbes was die fondasie vir sy teologie.

\subsection{Forbes se teologie ${ }^{5}$}

Forbes se teologie van antidiskriminasie, selfhelp en opvoeding is verhelder deur die donker lewensomstandighede van apartheid, diskriminasie en ongeregtigheid. Sy teologie was sterk onderskryf deur sy fokus op 'n God wat almal na sy beeld geskape het.

Hierdie teologie van Forbes, vind neerslag in die vele gesange wat hy geskryf het soos byvoorbeeld die "Ordening gesang" (1927), "O, seën die werk vandag gedaan" (1923), "Ons nasionale blomlied - die Protea - suikerbos" (1937) en die "Onze Volkslied” (1922).

Dus kon hy en die Volkskerk van Afrika in 1951 verklaar,

It finds that the political situation is showing certain tendencies which are having a marked effect on the peace of mind of the people, and in this way is hampering them in the exercise of their religious practices and in maintaining a worshipful mental attitude ... [T] he Volkskerk van Afrika has no hesitation in condemning any such measures which goes contrary to the basic tenets of its faith, and which seeks to deprive the Coloured person of his dignity as a man, created in the image of God. In fact, it owes its very existence to the refusal of its founders to accept conditions of inequality which it found humiliating, and it therefore protest against the proposed legislation as an assault on the citadel of the dignity of man (Volkskerk van Afrika, 29ste kerkverjaarsdag, 13 Mei 1922-1951:74).

5 Forbes het op 26 Augustus 1924 die eerste bruin Kommissaris van Ede geword; Volkskerk van Afrika, 34ste kerkverjaarsdag (1956:2-3). 
Vervolgens sal daar gekyk word na die drie sleutelaksente van Forbes se teologie naamlik antidiskriminasie, selfhelp en opvoeding.

\subsubsection{Antidiskriminasie}

Forbes was baie sterk gekant teen enige vorm van diskriminasie en hy het nie geskroom om die beleid van apartheid te veroordeel nie. Die volgende uitsprake van Forbes toon dan juis hoe sterk hy teen diskriminasie gekant was:

The original owners of Africa helped the foreign intruder with water, game, wood, and grass, which kept them alive. The foreigner became bold and strong, and in short claimed possession of Africa, and the once master became slave and servant to the intruder. This process of persecution had come down to them from those barbarous days when men to a large extent were saturated with the selfishness of the jungle - to kill, eat and destroy, to satisfy their greed. It was this get, grab and keep spirit which was responsible for segregation laws, economic oppression, narrow-mindedness, industrial wars and two scales of justice." (The Sun, 1940:11).

Verder skryf Forbes in sy "Goodwill message" die volgende woorde,

The coming of Jesus Christ to this sinful world, meant peace on earth, and goodwill towards ALL men ... Nations have risen because of the blessing of God, and have fallen because that blessing was abused. We will trust and not be afraid. This demon of selfishness, disintegrating families, creating God forsaken colour bars, will die out as Christ comes in" ("Goodwill message" in Cape Standard 1945:1).

Tydens die dertiende konferensie stel die Volkskerk van Afrika dit duidelik dat hulle die apartheidsbeleid van die regering verwerp en lees die resolusie dat hulle dit doen op grond daarvan dat die apartheidsbeleid van die regering onskriftuurlik en onbybels is.

In collaboration with other Christian churches and supported by the "side-by-side" policy of the Volkskerk van Afrika, we pray for its immediate withdrawal and the healing of the breach caused by discrimination, class distinction and that forced inferiority complex (Cape Times, 19 April 1949). 
Selfs gedurende die Tweede Wêreldoorlog het hy nie oor die onreg van apartheid geswyg wat diskriminasie op grond van velkleur verkondig het nie. In sy woorde sê hy,

We have entered upon the sixth year of terrible war, with bloodshed rife. Yet we do not see injustices remove, but the capitalistic system going all out to keep the underdog under, killing him soul and body through differential treatment, in all walks of life. This Godforsaken segregation policy, supports that vicious circle, will soon have to reckon up with almighty God, "for shall not the judge of the earth do right?” (The Cape Standard, 1945:7).

In 1946 skryf Forbes en sê,

We live in an unrighteous world full of injustices, abuse, discriminations, partiality, and favouritism (The Cape Standard, 1946).

Tog moedig hy die Volkskerk van Afrika aan om ten spyte van die onregverdige en diskriminerende omstandighede "to continue maintaining their devotion to God, loyalty to themselves and service to man and to improve their social and educational status" (The Cape Standard, 1946).

Die Volkskerk van Afrika se aanvaarding van die Belydenis van Belhar ${ }^{6}$ in 2013 het die anti-diskriminasie teologie van Forbes herbevestig en die Volkskerk van Afrika opnuut daartoe verbind om vir 'n nie-rassistiese, vrye, gelyke, regverdige en menswaardige samelewing te bly werk.

Die Belydenis van Belhar met sy aanhef wat geloof in 'n drie-enige God bely, asook die drie basiese artikels van eenheid, versoening en geregtigheid is juis die eienskappe van 'n samelewing waarin rassisme en diskriminasie bestry en oorwin kan word.

\subsubsection{Selfhelp}

Uit die mond van Forbes beteken selfhelp om selfstandigheid en verantwoordelikheid te vergestalt. In die konteks van gruwelike onderdrukking en ontkenning van mense se menswaardigheid en

6 Vir 'n teologiese en ekumeniese verstaan van die Belydenis van Belhar, sien Naudé (2010). 
hul vermoëns, beteken selfhelp om te protesteer teen enige vorm van ongeregtigheid, dit terwyl jy verantwoordelikheid neem vir jou eie toekoms.

Soos reeds vroeër in die artikel genoem, het Forbes sy ideë van selfhelp, eie aan die Volkskerk van Afrika gemaak. Reeds in sy stigtingsrede merk 'n mens die idee van selfhelp op wanneer Forbes sê,

Drawn from the various sections of the Christian community, these people ultimately resolved to form themselves into a Church, controlled by themselves, and for themselves, so that they may serve God with a free conscience, with liberty of spirit and in their own way (Volkskerk van Afrika, Goue Jubileumviering 1972:3).

Dus, die stigting van die Volkskerk van Afrika as 'n Christelike kerk vir die bruin mense, was juis om te wys dat ons selfstandig en verantwoordelik kan wees en dat ons menswaardigheid nie van ras of velkleur afhang nie.

Die selfhelp gedagte van Forbes kan verstaan word teen die historiese agtergrond van die ontstaan van die Volkskerk van Afrika. Hierdie selfhelp teologie van die Volkskerk van Afrika het samewerking met ander ingesluit, soos Forbes self verklaar,

We come to present ourselves in an open frank way for general acknowledgment as a society to help on very definite lines and to work side by side with the older and established Christian institutions for the betterment of our motherland (Volkskerk van Afrika, Goue Jubileumviering 1972:3).

Dit was hierdie selfhelp teologie wat gemaak het dat baie uit eie geledere mildelik bygedra het tot die groei van die Volkskerk van Afrika. Hiervan getuig die geld wat ingesamel is, gemeentelede wat baie keer self die bouwerk gedoen het en hoekstene asook vele ander meublemente geskenk het. Die Volkskerk van Afrika het ook deur hierdie selfhelp teologie grond bekom.

Met die lê van die eerste hoeksteen van die Skoolsaal in Banhoekweg, Stellenbosch in 1923 sê Forbes as volg,

It was a great day in the history of their people because it was the first time that a coloured lady (Ms B.J. Bergsteedt) had presented a foundation stone, and the first time that a coloured man had laid a foundation stone for the coloureds. We are just like the eagle, pushed 
out of the nest, only to bring us to our senses and to realise that we also have wings and to make us take hold of the policy of self-help (Cape Times 1923).

Hierdie selfhelp teologie van Forbes is tydens die eerste jaarlikse vergadering van die Volkskerk van Afrika bekragtig toe daar besluit is, "om magtige fondse in die lewe te roep om die onkoste en instandhouding van die Volkskerk van Afrika vir altyd te verseker" (Volkskerk van Afrika, Silver Jubilee Celebrations 1947:14).

Die selfhelp teologie van Forbes was nie 'n individualistiese benadering tot die lewe of 'n onttrekking uit die wêreld nie. Nog minder was dit 'n teologie wat op die "self" gegrond was. Dit was nie dwaalleer teen wat die Bybel of Christus geleer het nie. Die selfhelp teologie van Forbes het ten doel gehad om die bruin mense van sy tyd te laat besef dat hulle gelyk aan die blanke was, dat hulle oor kwaliteite en gawes beskik om God en medemens te kan dien, sonder om onder die drukkende en diskriminerende gesag van die blanke te leef. Waar die diskriminerende wette, mense se menswaardigheid ontken, wou Forbes met sy selfhelp teologie mense se menswaardigheid bevestig. Forbes wou mense met sy selfhelp teologie van 'n "slagoffermentaliteit" bevry en leer dat hulle op hul eie voete kan staan en hul geloof en vertroue in God moet stel, want God sal ook in hul behoeftes voorsien. Hy wou dat hulle verantwoordelikheid vir hul godsdienstige en morele lewe neem, sodat hulle uiteindelik verantwoordelike Christene en burgers van Suid-Afrika kan wees. Sy selfhelp teologie wou 'n kerk tot stand bring waar hulle vrylik en op hul manier God kon aanbid, en tot diens van hul medemens kan wees.

\subsubsection{Opvoeding}

As opvoeder en teoloog was die kinders se opvoeding vir hom belangrik. Dit is daarom geen wonder dat die Volkskerk van Afrika hul eerste kerkskool in 1923 te Kensington begin het nie. Teen 1946 was daar sewe dagskole, met 2000 leerders en 35 gekwalifiseerde onderwysers. Saam met die dagskole, het die Volkskerk van Afrika ook 'n kinderhuis vir kinders in Jonkershoekdam besit.

In 1927 stel Forbes hom verkiesbaar om op die Skoolraad (School Board) te dien, waar hy hom vir meer publieke skole, vrye en verpligte opvoeding en gelyke salarisse vir bruin onderwysers beywer het. 
By die begrafnisdiens van Alfred Davidse ${ }^{7}$ op 28 Oktober 1945 preek Forbes en sê,

He had faith in himself, faith in his people and faith in God, and he succeeded. Let his life be an example. His life should be an inspiration to our young men desirous of leading their people. In Davidse we had proof that it is not colour, but intellect which counts (The Cape Times Standard 20 November 1945:5).

By die jaarlikse vergadering van die Volkskerk van Afrika te Oudtshoorn in 1946, moedig Forbes die bruin mense aan om te midde van die diskriminerende wette en die feit dat hulle van geleenthede ontneem word, hulle steeds moet aanhou om hulle sosiale en opvoedkundige status te verbeter (The Cape Standard 1946).

Hierdie teologie van opvoeding sou juis die sosiale en morele situasie van dobbel, drinkmisbruik en dwelmgebruik (soos dagga) aanspreek. Dit moes die bruin gemeenskappe transformeer na 'n staat van geregtigheid wat 'n volk verhoog. Die Nuwe Afrikaanse vertaling lees, "Gehoorsaamheid aan die Here laat 'n volk sterk staan" (Spreuke 14:34).

Forbes se teologie van opvoeding kan Bybels gegrond word, want opvoeding gaan nie net om die bekom van kennis deur individue nie, maar moet die naaste en omgewing asook God kan dien. Watts in sy artikel "Towards a theology of education: Theology as underlabourer to Christian education" (n.d.:540) noem dat,

A theology of education ${ }^{8}$ is well illustrated by the narrative of God, through Moses, leading out and leading forth God's chosen people

7 The Cape Standard het as volg oor Alfred Davidse gskryf: "University authorities say he was one of their most outstanding, steady and painstaking students. They did not know that he was a waiter in his spare time" (The Cape Standard 1945:5). In dieselfde artikel het Forbes gesê: "Davidse, a painter's son, was born of poor respectable parents. They did all they could for him, but he had to persevere to attain his object, a B.A. degree at the University of Cape Town. (The Cape Standard 1945:5).

8 Soos Watts sou aanvoer: "At the most radical or foundational level, and from a holistic perspective, a theology of education prepares the ground for Christian educators to address four contextually interrelated questions: (a) What do we want Christian education to become? (b) What are we allowing it to be? (c) What does it mean to be "Christianly" educated? and (d) How does Christian education relate to other educational systems? In short, what is the aim, goal, or telos of Christian Education?...A theology of education is multifaceted and multidimensional. Across the various faith traditions, differing 
to freedom from bondage, and to enlightenment of the Kingdom of Heaven and its laws" (Deut 8:2; Isa 43:16)

Humphreys, opvoedkundige navorser, meen dat'n teologie van opvoeding aan die volgende kriteria moet voldoen:

Education is part of God's intent for mankind through creation and must have a "creational" component in that we must teach a God who overflows with love for his beautiful creation, and a creation that is good, to be used well, and to be cared for by all humans.

If this is so, then our education must reflect in all things the createdness of the earth and of mankind. Educators in this theological framework will therefore have the confidence of knowing that they are humble participants in God's reign on earth. Schooling for thankfulness, for joy and for contentment must be at the heart of what we do, because these are things for which humans were created" (Humphreys 2014:n.a.).

Humphreys argumenteer verder en sê omdat ons geskape is om in gemeenskap te wees, moet opvoeding in gemeenskap wees, sodat almal opgelei kan word in effektiewe en herstellende maniere om verhoudings te herstel wanneer hulle verbrokkel, en dus kan demonstreer hoe die lewe in die Koninkryk van God kan wees as ons dit in sy vervulling sou sien. Onderwys wat voortvloei uit hierdie teologiese voorveronderstelling, sou eerder samewerkend as mededingend wees, gerig op ' $n$ gesonde gemeenskap eerder as individualisties, terwyl die individualiteit en diversiteit van diegene wat saamwerk, vereer word.

Hy is van mening dat,

though interrelated theologies of education occur, and this variation is conducive to a healthy dialectic and dialogue. Analogically, state, religious, and independent school systems develop and oversee their specific alternative programs, which differ from but interrelate to one another... At its deepest level, a theology of education operates as an underlabourer to guide, nourish and empower Christian education. The significance of a theology of education framework for Christian education is of such import that it needs to be approached with an epistemic humility that recognises and accepts the seriousness of the endeavour, while also appreciating the inadequacies of the human mind when contemplating the divine (Watts n.d.:534-535). 
Education must be for hope - the hope of the resurrection and the restoration of God's life on earth. It must therefore be an education that makes for peace rather than for striving, for contentment rather than acquisition, for others and their flourishing rather than the "best we can be" for our own sake, for family, community and place rather than for upward mobility and a professional, specialised study divorced from the community it serves (Humphreys 2014:n.a.).

Dit is daarom krities belangrik om die vroeëre geskiedenis van die Volkskerk van Afrika te belig.

\section{Die Volkskerk van Afrika: vroeë geskiedenis}

Die Volkskerk van Afrika (aanvanklik gesien as beweging en wat as die Verenigd Nationale Kerk van Afrika, Onze Volkskerk bekend gestaan het) het sy naam gekry na 'n vergadering tussen afvaardigers van Stellenbosch en eerwaarde Forbes in sy huis op 26 Maart 1922. Op die vergadering het broer Paul Rhode voorgestel dat die naam Volkskerk van Afrika onder geen omstandighede verander of vertaal moet word nie. Die voorstel is deur broer JC Fester gesekondeer en deur die gesamentlike vergadering aangeneem (Volkskerk van Afrika, Silver Jubilee Celebrations 1947:52). Dit word vermeld dat na die stigting van die Volkskerk van Afrika al die kinders van die stigters en gemeentelede destyds uit die verskillende sendingskole verban is. 'n Verdere hartseer gebeurtenis was toe die kinders van JJ Alexander (27 April 1922), SJ Hector (23 Mei 1922) en P Okkers (26 Oktober 1922) sterf, hulle saam met misdadigers in die bandietebegraafplaas begrawe moes word omdat die Volkskerk-ouers die reg ontsê was om hul afgestorwenes in die kerkhof van die sendelinge te begrawe.

Alhoewel Forbes die stigterslede probeer oorhaal het om by die Congregational Kerk, Harrington, aan te sluit, het hulle volstrek geweier en deur selfstandigheid en die nasionale gedagte beklemtoon. Die idee van 'n eie onafhanklike kerk vir die bruin mense sou nie net vir Stellenbosch wees nie, maar vir die hele Suid-Afrika (Volkskerk van Afrika, Silver Jubilee 1947:49).

Die Volkskerk van Afrika van Forbes en die stigters toon 'n kerk van mense wat sterk gekant was teen enige vorm van segregasie, onderdrukking, 
ongelykheid en diskriminasie. Onder hul leiding was die lede van die Volkskerk van Afrika oorgehaal om te help, mekaar te help en veral hulself te help. Dit was 'n geloofsgemeenskap wat as sosiale beweging begin was om veral die morele, geestelike en sosiale uitdagings van die dag aan te spreek. Dit was'n geloofsgemeenskap van mense wat hul geloofsoortuigings prakties gedemonstreer het, deur byvoorbeeld op te staan vir geregtigheid. Hulle het daarom ruim bygedra om die kerkkas finansieel te versterk na mekaar om te sien.

Jaftha Katts het 'n beursfonds in sy naam (Jaftha Katts Beursfonds) gestig en leen 'n verdere bedrag aan die Volkskerk van Afrika en stel so die genootskap in staat om 'n pastorie sonder enige versekering aan te koop (Volksrust, Marsden Road, Walmer Estate). Die Forbes-familie neem intrek op 1 September1922. Broer en suster G Brownbill skenk tien plotte grond in Dieprivier (17 Mei 1924).

Broer A Hector van Stellenbosch skryf oor hoe trots, geloof en standvastigheid nie by die stigterslede ontbreek het nie, selfs nie toe van hulle met verbanning uit hul wit kerke gedreig was omdat hulle die nuwe beweging ondersteun het (Volkskerk van Afrika, Silver jubilee 1947:49).

Met verwysing na die aantal mense wat die vieringe van die Kerk se verjaardag bygewoon het, byvoorbeeld met die derde verjaarsdagviering, meld die Cape Times van 18 Mei 1925:

A very happy audience crowded the Banqueting Hall, recently the occasion being the celebration of the third anniversary of the Volkskerk van Afrika by a social.

By die tweede Broederskapsdiens in die Kaapse Stadsaal, was daar oor die drieduisend mense (Die Burger, 30 November 1925).

Neem 'n mens verder in ag die vinnige groei (teen die sesde verjaarsdag het die Volkskerk van Afrika van 250 lede na 1500 lede, 1 leraar met'n hulpleraar, tien aanbiddingsplekke, 1 pastorie, 4 selfhelp takke, 4 dagskole met 550 kinders en 10 leerkragte, 11 Sondagskole met 24 Sondagskoolonderwysers gegroei) en gesien dat reeds 16 van ons huidige 25 gemeentes teen 1955 gestig was (ingeslote Kaapstad Gemeente wat op Sondag 12 Augustus 1979 moes sluit), blyk dit dat die mense ontvanklik was vir die evangelie en dat hulle 'n lewendige spiritualiteit gehandhaaf het. 
Forbes (wat die Volkskerk van Afrika vir 33 jaar gelei het) en sy stigters het 'n kerk gestig en nagelaat wat God en mens wou dien.

\section{Die relevansie van die Volkskerk van Afrika}

Met die viering van die $500^{\text {ste }}$ jaar van die Hervorming in 2017 en nou met die belewenis van die Covid-19 pandemie in 2020/2021, is dit gepas om te vra wat die relevantheid van die kerk is wat Forbes ${ }^{9}$ en sy stigters begin het.

Die politieke speelveld het sedert 1922 verander. Suid-Afrika het sedert 1994 'n nuwe grondwet wat beginsels soos demokrasie, gelykheid, geregtigheid, vryheid en menswaardigheid onderskryf. Tog worstel ons nog met probleme soos uitsluiting, ontkenning, rassisme, ${ }^{10}$ seksisme, ekonomiese ongelykheid en daarom ook met erge geweld en korrupsie.

Soos in die dae van Forbes en die stigters, kan ons hierdie uitdagings net aanpak met 'n sterk geestelike grondslag en 'n sy-aan-sy benadering.

Die Volkskerk van Afrika se selfhelp teologie is nog van krag, maar moet uitgebrei word. Die Volkskerk van Afrika moet besef hulle het nou ook ander vennote, ondersteuners, ekumeniese en internasionale hulp waarop hulle kan steun om hul profetiese rol vandag te vervul. Prof. JJ Kritzinger skryf interessant in sy artikel "Dependency and Indepedence. Perspectives on the (expensive) way of being church" soos volg:

The pre-occupation with financial matters, necessary to make ends meet, is bearing tragic fruit in the life of the church ... the second negative result of the situation is the inward centeredness caused by the financial struggles. All energy and attention are in many churches focused on this one issue: to survive financially. There is

9 By die 18de jaarlikse vergadering van die Volkskerk van Afrika, 6-9 Oktober 1956 te Stellenbosch, is besluit dat die eerste Sondag van Augustus jaarliks as gedenkdag aan Forbes gewy sal wees.

10 In hul boek Saam in Suid-Afrika huldig Pieter van Niekerk en Chris Jones die mening dat rassisme nog net so lewendig in Suid-Afrika is. "Dit is asof die sluimerende rassisme na 1994 se reënboogdroom met 'n groot knal oopgebars het. Die rassismesweer se ontsteking is besig om dit wat mooi en uniek aan Suid-Afrikaners is te besmet ... Die diskriminerende rasgerigte insidente, optredes en uitlatings van sommige persone, groepe en instansies veroorsaak rassespanning, verdeeldheid, haat en konflik onder Suid-Afrikaners." (2017:8-9). 
often a total disregard for that dimension that gives meaning to the existence of the church: to be God's representative and witness. The focus is neither on God and the worship of God, nor on the world, in which God's good news is to be proclaimed (Kritzinger 1996:18-19).

Hy sluit af en sê:

Such a church is a disgrace, no positive witness to the Lord ... Such a church is not a healthy environment for Christian people. [T] he church is of no help if it is itself poisoning the people with the virus of not taking responsibility for its own affairs. The church should take the lead with a theology and practice of responsibility and reconstruction (1996:18-19).

Aanvanklik het die Volkskerk van Afrika in die vroeë jare vinnig gegroei. Tans ervaar die kerk stagnasie en 'n afname in getalle. Gemeentes word stadiger gestig. Bywoning van eredienste en die weeklikse bidure neem af. Die redes hiervoor is legio, tog laat dit 'n mens wonder oor die diepte van hul geestelikheid, soort spiritualiteit, toegewydheid en hul verbintenis om die Volkskerk van Afrika te laat groei.

Met die kennis van die vroeëre Volkskerk van Afrika en sy mense en teen die agtergrond van hedendaagse uitdagings, moet die Volkskerk van Afrika volhard, of soos hul leuse leer, "Volhard in geloof", om teen enige vorm van uitsluiting, diskriminasie en ongelyke behandeling op te staan. Die Volkskerk van Afrika sal moet aanhou om vir gelyke en gehalte onderrig van sy kinders te veg. Die Volkskerk van Afrika sal moet aanhou om teologiese verryking voor te staan.

Die Volkskerk van Afrika sal moet toesien dat hul werksaamhede as geloofsgemeenskap getuig van morele opheffing, geestelike onderrig en teologiese toerusting om mense geestelik te verdiep sodat hulle in staat gestel kan word om hierdie kwessies van die dag aan te spreek. Dat hulle die artikels van ons land se grondwet kan uitleef en almal help rig om verantwoordelike landsburgers te wees.

Was dit reg om die Volkskerk van Afrika te stig? Was die kerk toe relevant? En is die kerk vandag relevant? 
Daar kan aangevoer word dat die besluit om die Volkskerk van Afrika te stig, inderdaad reg was. Die agtergrond van diskriminasie, rassisme en onderdrukking regverdig die onderneming. Die redes, soos uiteengesit in die stigtingsrede van die Volkskerk van Afrika, naamlik om 'n kerk te wees wat deur hul eie mense bestuur word om 'n bydrae te lewer tot die geestelike, opvoedkundige, sosiale en morele opbou van ons samelewing en Suid-Afrika, onderskryf juis die beweegrede tot stigting.

Die kerk se relevansie lê juis opgesluit in die feit dat alhoewel die politieke bestel sedert 1994 verander het, is die kerk se stem nog steeds nodig, veral in terme van die aanspreek van rassisme, diskriminasie, ekonomiese ongelykhede, groeiende korrupsie, geweld, morele verval en misdaad, onmenswaardige behandeling van veral mense met 'n homoseksuele en ander seksuele oriëntasie. In dié sake moet die kerk profeties ${ }^{11}$ praat en met moed en oortuiging optree. Met die kerk se aanvaarding van die Belydenis van Belhar, kan die Volkskerk van Afrika nie anders nie, want prinsipieel bely hulle in kort om te staan waar God staan - en dit is aan die kant van die arme en die onderdrukte.

In die stryd teen onderdrukking en ongeregtigheid was Forbes en die stigters onverskrokke. Hulle was sterk verbind tot nasionale eenheid veral onder die bruin mense en tot die bou van 'n samelewing waar vryheid, gelykheid, geregtigheid en menswaardigheid die norm is.

\section{Konklusie}

Die Volkskerk van Afrika het sy ontstaan aan die geestelike verlange van die bruin mense om 'n eie kerk te hê wat deur hul eie mense bestuur word en waar gelowiges op hul eie manier God kan aanbid. 'n Kerk wat tot diens van hul naaste asook hul Vaderland kan wees en wat 'n bydrae wil lewer om van die samelewing 'n regverdige, gelyke en menswaardige samelewing te maak.

11 Oor die profetiese stem van die ekumeniese kerk asook oor die ontstaan van die Volkskerk van Afrika en die ervaringe van die stigters en die Volkskerk van Afrika se rol in die Ekumene, sien my artikel "The prophetic voice of the ecumenical church in South Africa and the role of the Volkskerk van Afrika" in Katts (2015) Sien ook 'n verdere artikel van my oor die "Volkskerk van Afrika: Being Reformed in Reformation 500" (Katts 2017). 
Forbes en die stigters het volhard om mense geestelik te voed sodat hulle hul geloofsoortuigings kan gebruik om ander en die samelewing tot hoër hoogtes in terme van opvoeding, godsdienstigheid en burgerlike verantwoordelikhede kan neem. Alhoewel die kerk aanvanklik vir die bruin mense was, is reeds in die latere 70s besluit om die kerk vir almal oop te stel.

Dieselfde morele, politieke en ekonomiese uitdagings wat Forbes en die stigters van die Volkskerk van Afrika beveg het, is nog met ons in die een of ander vorm. Die Volkskerk van Afrika kan dus nie gerus of passief wees in hul roeping om God, mens en samelewing te dien met die oog op 'n beter land nie.

Om 'n kerk van integriteit en geloofwaardigheid in die volle sin van die woord te wees, moet die kerk se ledetal ook 'n diversiteit van gelowiges weerspieël. Dit bly die uitdaging vir die Volkskerk van Afrika vandag.

\section{Bibliografie}

Botha, J en Naudé, P 1998. Op pad met Belhar. Goeie nuus vir gister, vandag en môre. Pretoria: JL Van Schaik Uitgewers.

Botha, SJ 1973. Die Volkskerk. Pretoria: Haum.

Humphreys, Huw 2020. Towards a theology of education. [Intyds]. Beskikbaar: https://huwhumphreys.wordpress.com/2014/09/29/ towards-a-theology-of-education/. [Besigtig: 13 Nov. 2020].

Jonker, W 1998. Selfs die kerk kan verander. Kaapstad: TafelbergUitgewers.

Katts, DJ 2017. Volkskerk van Afrika: Being Reformed, in Dr Kobus Gerber (ed.). Reformation 500. Some South African perspectives. Wellington: Christian Literature Fund, 47-58.

Katts, DJ 2015. The prophetic voice of the ecumenical Church in South Africa and the role of the Volkskerk van Afrika. Stellenbosch Theological Journal 2015(1): 187-200. 
Kritzinger, JJ 1996. Dependency and Independence: Perspectives on the (expensive) way of being church. Praktiese Teologie in Suid-Afrika 11(1):14-24

Naudé, PJ 1999. Onder die skewe reënboog. 'n Evangelie van Hoop vir die gewone mense in 'n gekwelde land. Kaapstad: Lux Verbi.

Naudé, PJ 2010. Neither calendar nor clock. Perspectives on the Belhar Confession. Grand Rapids, Michigan: William Eerdmans Publishing Company.

Smit, D 2013. Oor die Belydenis van Belhar: Ontstaan, inhoud, resepsie, relevansie. In Hansen, L (red). Opstelle oor Gereformeerd wees Vandag. Versamelde Opstelle 4. Stellenbosch: Sun Media.

Van Niekerk, P en Jones, C 2017. Saam in Suid-Afrika. Kaapstad. Lux Verbi.

Watts J. n.d. Towards a Theology of Education: Theology as Underlabourer to Christian Education. [Intyds]. Beskikbaar: https:// christintheclassroom.org/vol_37a/37a-cc_529-548.pdf [Besigtig: 13 November 2020].

\section{Koerantberigte}

Cape Standard, 1945

The Torch, 4 Oktober, 1948.

Die Burger, 15 June, 1928

Cape Times, 18 Mei, 1925

Die Burger, 30 Nov. 1925

Die Burger, 29 Jan. 1925

\section{Bronne van die Volkskerk van Afrika}

Volkskerk van Afrika - Goue Jubileum, 1972

Volkskerk van Afrika - Silver Jubilee Celebrations, 1947

Volkskerk van Afrika - 34ste Kerkverjaarsdag, 1956

Volkskerk van Afrika - 29ste Kerkverjaarsdag, 1951 